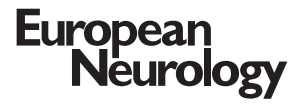

Eur Neurol 2014;72:79-80

DOI: $\underline{10.1159 / 000358514}$
Received: December 3, 2013 Accepted: January 8, 2014 Published online: June 4, 2014

\title{
Emerging New Markers of Stroke Risk and Prognosis
}

\author{
Shailendra Kapoor \\ Private practice, Mechanicsville, Va., USA
}

Dear Sir,

The past few years have seen the identification of a number of promising markers to assess the risk as well as treatment outcomes in strokes [1].

One emerging and promising marker to predict risk and prognostic outcome in stroke is asymmetric dimethylarginine (ADMA). Worthmann et al. [2] in a recent study have confirmed that ischemic stroke patients have higher serum ADMA concentrations. A mean serum ADMA level of $1.49 \mu \mathrm{mol} / \mathrm{l}$ has been noted in early stroke patients in contrast to a mean concentration of $0.97 \mu \mathrm{mol} / \mathrm{l}$ seen in nonstroke patients [3]. Serum homocysteine is an independent parameter that has a significant impact on serum ADMA levels. A poor clinical prognosis and outcome is seen in stroke patients with serum ADMA levels in excess of $0.53 \mu \mathrm{mol} / \mathrm{l}$, a week after the stroke [4]. Interestingly, statin therapy has a significant negative impact on serum ADMA levels in patients who have devel- oped ischemic stroke [5]. Serum symmetric dimethylarginine (SDMA) has similar value in assessing the outcome in stroke patients. For instance, a mean SDMA concentration of $0.51 \mu \mathrm{mol} / 1$ is seen in nonstroke individuals in contrast to a higher mean concentration of $0.89 \mu \mathrm{mol} / 1$ seen in stroke patients [6]. Similarly, serum SDMA appears to be an independent parameter influencing post-stroke total mortality. For instance, a worse clinical outcome and prognosis is seen in stroke patients with SDMA concentration in excess of 0.59 $\mu \mathrm{mol} / \mathrm{l} 24 \mathrm{~h}$ following the stroke onset [7]. In fact, Schulze et al. [6] have reported a hazard ratio of 2.41 for SDMA. Interestingly, the association between SDMA and total mortality remains significant and is not influenced by renal function [8].

Another emerging marker is MMP-9. MMP-9 significantly modulates and regulates neuroinflammation in the early stages of ischemic stroke. For instance, Ulrich et al. [9] in a recent study have demonstrated a close and direct association between the volume of acute brain infarct lesions and MMP-9 mRNA levels in peripheral blood mononuclear cells. MMP-9 mRNA levels also significantly impact poststroke survival. For instance, the serum MMP-9 mRNA levels in stroke survivors are almost one third of the levels noted in stroke nonsurvivors [10]. Serum MMP-9 levels also are a sensitive marker of stroke development. For instance, the mean serum MMP-9 level in individuals with ischemic stroke is 172 $\mathrm{ng} / \mathrm{ml}$ in contrast to $57 \mathrm{ng} / \mathrm{ml}$ in normal nonstroke individuals [11]. In addition, patients on t-PA therapy who exhibit upregulated MMP-9 expression are more likely to develop cerebral hemorrhages.

The above markers have shown considerable promise in assessing the risk as well as outcome in strokes. Hopefully, the coming few years will see their regular application in day-to-day neurology.

\section{KARGER}

E-Mail karger@karger.com www.karger.com/ene
(C) 2014 S. Karger AG, Base

0014-3022/14/0722-0079\$39.50/0
Shailendra Kapoor

45 Crossing

Mechanicsville, VA 23111 (USA)

E-Mail shailendrakapoor@yahoo.com 


\section{References}

1 Shibazaki K, Kimura K, Sakai K, Fujii S, Aoki J, Saji N: Brain natriuretic peptide on admission as a biological marker of long-term mortality in ischemic stroke survivors. Eur Neurol 2013;70:218-224.

-2 Worthmann H, Chen S, Martens-Lobenhoffer J, et al: High plasma dimethylarginine levels are associated with adverse clinical outcome after stroke. J Atheroscler Thromb 2010;18:753-761.

$>3$ Leong T, Zylberstein D, Graham I, et al: Asymmetric dimethylarginine independently predicts fatal and nonfatal myocardial infarction and stroke in women: 24-year follow-up of the population study of women in Gothenburg. Arterioscler Thromb Vasc Biol 2008;28: 961-967.
4 Chen S, Li N, Deb-Chatterji M, et al: Asymmetric dimethylarginine as marker and mediator in ischemic stroke. Int J Mol Sci 2012; 13:15983-6004.

5 Nishiyama Y, Ueda M, Otsuka T, et al: Statin treatment decreased serum asymmetric dimethylarginine (ADMA) levels in ischemic stroke patients. J Atheroscler Thromb 2011; 18:131-137.

6 Schulze F, Carter AM, Schwedhelm E, et al: Symmetric dimethylarginine predicts allcause mortality following ischemic stroke. Atherosclerosis 2010;208:518-523.

7 Luneburg $\mathrm{N}$, von Holten R, Topper RF, Schwedhelm E, Maas R, Boger RH: Symmetric dimethylarginine is a marker of detrimental outcome in the acute phase after ischaemic stroke: role of renal function. Clin Sci 2012; 122:105-111.
8 Nishiyama Y, Ueda M, Katsura K, et al: Asymmetric dimethylarginine (ADMA) as a possible risk marker for ischemic stroke. J Neurol Sci 2010;290:12-15.

9 Ulrich NH, Dehmel T, Wittsack H, Kieseier B, Seitz R: Peripheral blood levels of matrix metalloproteinase-9 predict lesion volume in acute stroke. Neurol Sci 2013;34:379-382.

10 Graham CA, Chan RW, Chan D, Chan CP, Wong LK, Rainer TH: Matrix metalloproteinase 9 mRNA: an early prognostic marker for patients with acute stroke. Clin Biochem 2012;45:352-355

11 Cojocarui I, Cojocaru M, Sapira V, Socoliuc G, Hertea C, Paveliu S: Changes in plasma matrix metalloproteinase-9 levels in patients with acute ischemic stroke. Rom J Intern Med 2012;50:155. 